\title{
FOOD PRODUCT PRICES AND ITS IMPLICATIONS FOR FOOD SECURITY IN NIGERIA
}

\author{
*EFFIONG, J.A.L AND EZE, E.U. \\ Department of Agric Engineering \\ Federal Polytechnic Nekede, P.M.B. 1036, Owerri, Nigeria
}

*Corresponding author's E-mail:effiongjal@yahoo.com

\begin{abstract}
The study examined the prices of food products and its implications for food security in Nigeria. Data was obtained from Federal Office of Statistics and was analyzed using histogram and and price index number (Laspyres index). The study show that food price inflation is caused by frequent hike in the prices of petroleum products coupled with poor performance of the agricultural sector. Between 1996 to 2002, fuel official price rose by 136 percent and is accompanied with higher price index values in the food component of the annual average composite consumer price index. A similar phenomenon is observed between 2003 and 2005. The study further revealed that it is the poverty syndrome occasioned by a lack of purchasing power coupled with food price inflation that renders the populace vulnerable to food insecurity.. Food insecure households face a significant risk of food consumption falling below a critical level with regards to health and survival. A rise in the price of food does not necessarily raise incomes of food producers. This may not induce a downward shift in the supply curve in the long run. The study recommends providing poor (food insecure) people with opportunities to earn adequate incomes, ensuring abundant food supply from domestic production, adequately maintained rural feeder roads, banning of motor park touts, halting of police extortion at check points and provision of cheap and adequate supply of fuel.
\end{abstract}

Keywords: food insecurity, poverty, price index, inflation, petroleum products, hike

\section{INTRODUCTION}

The vital role that food plays in the life of man is well recognized. In order to maintain health, derive sufficient energy to carry on in life processes, there should be access to food that is adequate in terms of quality and quantity. Moreover, this food must be affordable. Price plays a crucial role in people's access to food. The economy of Nigeria is presently dominated by the petroleum sector and prices of petroleum products have had a determining impact on the prices of goods and services. Frequent hikes in the prices of petroleum products is known to offset an inflationary spiral that eventually brings about an increase in the prices of goods and services for as much as 200 to 500 percent. This partly accounts for unstable prices.

The poor performance of agriculture in Nigeria which was occasioned by an oil boom created serious distortions in the economy. The 1970-79 period witnessed a decline in agriculture's share in the GDP from 44.6 to an average of only 24 percent. Agriculture sector's share of the GDP declined from about 31 percent in 1973 'to about 23 percent in 1979 and 22 percent in 1980. Between 1981 and 1985 the percentage share fluctuated between 21 percent and 23 percent. The contribution of the agricultural sector to the country's GDP has continued to decline over time (FGN, 1989). Consequently, the capacity of Nigeria's Agriculture to provide food to meet domestic requirements has also declined. The index of domestic output of staple foods which average $145.9(1975=100)$ during 1960-70 declined to 90.4 during 1971 to 1980 and it stood at an average of 73.1 for 1981 to 1984 . Consequently 
demand pressures on available food supplies which has risen due to the astronomic growth in population from 56 million in 1963 to an estimated 140 million in 2006. This has resulted in soaring domestic prices and imports in recent years especially for those foods with income elastic demand (Balogun, 1986). The current level of food price inflation largely driven by increases in the food component of the consumer price index is the source of concern to low income groups who suffer from a lack of food security mainly caused by a lack of purchasing power.

The costs of inadequate diets to individuals, families and to nations as a whole can be enormous. Inadequate diets increase people's vulnerability to diseases and parasites, reduce strength, curtail the benefits of schooling and training programmes and result in a general lack of vigour, alertness and vitality of the affected groups. Low productivity due to inadequate human capital depresses output and hence income, making it more difficult for families and nations to extricate themselves from the cycle of poverty (Reutlinger, 1987 and Effiong, 2005).

The Objectives of the study include to

$i$, examine the food supply in Nigeria.

ii, identify the reasons for food price inflation.

iii, examine the linkages between poverty and food security.

iv, examine the implication of food price increase on food security of low income groups who constitute majority of the populace.

\section{METHODOLOGY}

Data for this study was obtained from National Bureau of Statistics and was analyzed using histogram and price index number (Laspyres index). Supplementary data was obtained from journals, and other publications relevant to this study.

\section{Food Supply Situation In Nigeria}

About 90 per cent of the food consumed in Nigeria is supplied by small scale producers of peasant background scattered all over the country in rural settings. With very few exceptions, agricultural production is carried out following traditional cropping patterns with rudimentary tools and corresponding low outputs. As a result each farmer only has a marginal output to offer for sale after meeting family needs.

Surveys by [Sebiola, 2004] and [Igben, 2001] show that across the country 44 percent of male farmers and 72 percent of female farmers cultivate less than one hectare per household. Crop yields are low because farmers lack access to farm inputs. In particular, inadequate access to fertilizer is a real problem in many parts of the country where farmers have to cope with diminishing soil fertility. The situation is aggravated by the fact that many farmers have access to only small parcels of land for cultivation. As the population swells and puts pressure on diminishing resources, escalating environmental problems further threatens food production. Land degradation, as a result of extensive agriculture, deforestation and overgrazing, is already at an alarming level in many parts of the country. Drought has become common in the north, while in the south, erosion provoked by heavy rains, floods and oil pollution is a major problem (IFAD, 2007). Moreover with poor state of rural roads, evacuation of farm produce becomes very difficult. The corollary is a glut in producing areas at harvest periods with corresponding low prices of agricultural products with farmers incurring losses. This perpetuates the poverty cycle of rural dwellers whose major occupation is agriculture. With this scenario, food production could not keep pace with population growth. There is pressure on available food supplies with consequent spiraling of food prices. This further aggravates the food security problem. 


\section{Petroleum Product Price Hikes And Food Prices}

The pervasive nature of petroleum product prices in increasing economic hardships and growing poverty in Nigeria is well recognized. This is due to the fact that the economy of Nigeria revolves around the petroleum industry and prices of petroleum products have had a contagious effect on the prices of goods and services. As at 2004 petrol pump prices in Nigeria was estimated to be 68 times higher than what it was 13 years ago in 1991, Center for Petroleum Information (CPI, 2004). In a FAO [2005] report, it was observed that soaring petroleum prices drive up prices for agricultural products (Vanguard, 2007). Incidences of fuel price hikes have been known to push up transportation costs by more than 200 percent which in turn accentuates food price inflation by the same magnitude. Owing to the dysfunctional state of Nigerian refineries arising from frequent breakdowns, instances of fuel shortages have been prevalent and persistent. At such instances, fuel cannot be purchased at official rates at filling stations but is readily available at black markets at very exorbitant rates (sometimes as high as 500 percent the official rate). Those who patronize petrol stations may spend days on queues without getting fuel. Fuel scarcity appears to be the deliberate creation of NNPC as it usually precedes official hikes in the prices of petroleum products. With the deregulation of the downstream oil sector; major oil marketers always have "limited" quantity of fuel to sell while independent marketers and black marketers who sell above the official rate have fuel at all times.

Table 1: Petroleum Products Retail Price Trend

YEAR

1985

1986

1987

1988

1989

1990

1991

1992

1993

1994

1995

1996

1997
PRICE/LITRE

0.18

N.A

0.39

N.A

N.A

0.51

0.60

N.A

3.25

N.A

N.A

11

11 
1998

1999

2000

2001

2002

2003

2004
11

20

22

N.A

26

31

41

Source: FOS, 2005

Note: $N A=$ Not Available

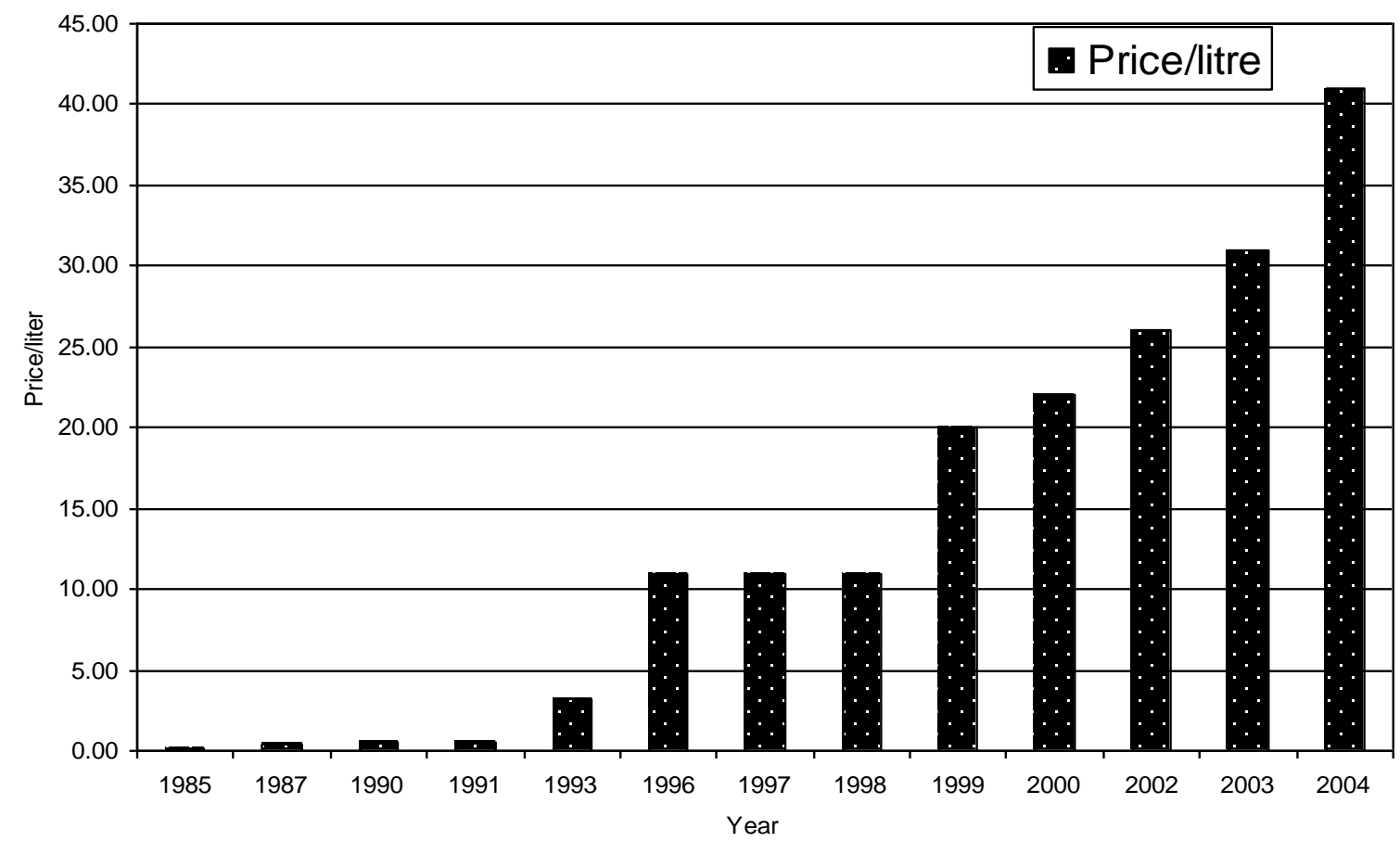

Fig. 1: Petroleum products retail price trend

\section{Source: From Table 1.}

From Table 1 and Figure 1, it can be observed that in 1985 the price per litre of gasoline stood at N 0.18. By 1987 it had risen to N0.39 representing an increase of 216\%. Between 1990 and 1993 fuel price had jumped from N0.51 TO N3.25 representing an increase of $637 \%$. This could be attributed to the gradual removal of subsidy on petroleum products and the fall in the value of the Naira owing to devaluation. The price of fuel was however stable between 1996 and 1998. This could be due to the fact that government was exercising restraint in obvious response to public outcry and riots over frequent hike of fuel prices. Thereafter, fuel prices continued to steadily increase between 1999 to 2000 . The increase could have been carried by government in response to the increase in national minimum wage and further removal of subsidy on petroleum products. The steady rising trend in Figure 1 corroborates this fact. 
Transfer Cost Component And Food Price Inflation

\begin{tabular}{lllllllllll}
\hline COMMODITY & 1996 & 1997 & 1998 & 1999 & 2000 & 2001 & 2002 & 2003 & 2004 & 2005 \\
\hline
\end{tabular}

Transfer cost which is the cost of moving food products from one point to another is determined to a great extent by the cost of fuel. This is the amount paid by a trader to move goods from one point to another. The cost of transporting products from production to consumption centres could be very outrageous for the following reasons.

a) Transport costs which is influenced significantly by the price of fuel. The mere anticipation of an increase in the price of petroleum products makes fuel station operators to hoard their fuel. This creates artificial scarcity and results in fuel prices being pushed up by as much as 500 per cent. Transporters respond by also increasing transportation costs by the same magnitude.

b) Distance between production and supply destination and the nature of rural roads. Nigeria's rural road network is one of the least developed in sub-Saharan Africa. Rural roads are virtually inaccessible during rainy seasons. And where there is a marketable surplus, it is not always easy to reach the markets (IFAD, 2007). The rate of wear and tear on vehicles and risk in plying rural roads is high hence transporters charge exorbitant rates.

c) The number of police checks along the route where the driver has to settle the police at each point coupled with the amount the driver has to pay to motor park touts. Drivers build up all these costs in their charges.

d) Handling charges: These include loading, unloading and packing goods. These involve costs incurred in loading goods into a vehicle after purchase; it also includes the costs of buying materials for use in properly packing goods in preparation for transit such as bags, baskets, cartons, crates etc. This is done to prevent damage to the product in transit. Handling charges also includes the cost of unloading the product after it has reached its destination.

\section{Price Indices For Food}

In examining the different components of the consumer price index as can be observed in Table 2, it is clear that the development in different commodities varies significantly. Prices indices show price movement over time. Between 1996 to 2002, food prices have tended to increase significantly. Fuel price as can be observed in Table 1 was stable between 1996 and 1998 yet food prices was rising astronomically during the same period as can be seen in Table 2. This was because even though the official price remained the same throughout the period, government and fuel dealers deliberately created artificial scarcity with fuel disappearing from filing stations but available at black markets at more than $100 \%$ the normal official rate. Between 1998 and 1999 food prices soared in response to a 82\% increase in the price of petroleum products. The index for 1999 is lower than 1998. This is accounted for by the fact that 1996 was taken as the base year for the period 1996 to 1998 while 1999 was taken as the base year for the period 1999 to 2002.This explains the differences in the index values obtained. Between 1998 and 2000, fuel prices increased by 100 per cent (see Table 1) and is accompanied by rising price indices. Between 1996 -2002 the official fuel price rose by 136 per cent hence, higher index values. Similarly from 2003 to 2005, the food component of the annual average composite consumer price index has been observed to rise steadily. 
Journal of Agriculture and Social Research (JASR) VOL. 10, No. 1, 2010

\begin{tabular}{|c|c|c|c|c|c|c|c|c|c|c|}
\hline Food & $2,630.70$ & $2,940.00$ & $3,44.43$ & $3,074.63$ & $3,14.88$ & $4,031.14$ & $4,560.73$ & 102.28 & 117.17 & 144.15 \\
\hline $\begin{array}{l}\text { Food \& Non } \\
\text { Alcoholic }\end{array}$ & - & - & - & - & - & - & - & - & - & - \\
\hline $\begin{array}{l}\text { Beverage } \\
\text { Alcoholic } \\
\text { Beverage }\end{array}$ & $2,463.30$ & $2,655.62$ & $3,460.68$ & $2,846.22$ & $3,148.27$ & $4,359.24$ & $5,409.00$ & 101,51 & 112.59 & 211.39 \\
\hline $\begin{array}{l}\text { Tobacco and } \\
\text { Kola }\end{array}$ & & & & & & & & & & \\
\hline $\begin{array}{l}\text { Clothing and } \\
\text { Footwear, } \\
\text { Housing, Water } \\
\text { \& Electricity }\end{array}$ & $2,657.70$ & $2,974.62$ & $2,985.85$ & $2,978.85$ & $3,074.63$ & $3,068.35$ & $3,072.06$ & 110.51 & 118.38 & 119.05 \\
\hline $\begin{array}{l}\text { Gas and Other } \\
\text { Fuel }\end{array}$ & $2,394.20$ & $2,535.87$ & $3,475.90$ & $4,945.50$ & $6,067.73$ & $6,029.09$ & $6,502.81$ & 166.88 & 141.04 & 158.02 \\
\hline 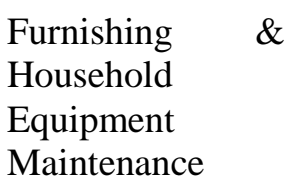 & $3,464.30$ & $3,566.52$ & $2,886.52$ & $3,627.08$ & $3,821.33$ & $3,947.35$ & $4,059.90$ & 106.02 & 112.60 & 125.67 \\
\hline Health & $2,728.60$ & $3,131.87$ & $4,095.67$ & $3,413.73$ & $3,625.89$ & $2,828.55$ & $3,565.45$ & 16.53 & 123.11 & 26.00 \\
\hline Transport & $3,022.80$ & $3,378.90$ & $4,434.61$ & $4,449.31$ & $4,726.80$ & $5,062.85$ & $5,275.55$ & 00.14 & 119.72 & 125.53 \\
\hline Communication & - & - & - & - & - & - & - & 100.41 & 167.64 & 233.58 \\
\hline $\begin{array}{l}\text { Recreation } \quad \& \\
\text { Culture }\end{array}$ & $2,878.40$ & $3,580.00$ & $3,856.34$ & $4,183.66$ & $4,650.33$ & $5,283.15$ & $5,811.78$ & 111.74 & 123.00 & 119.28 \\
\hline Education & - & - & - & - & - & - & & 118.70 & 135.23 & 144.40 \\
\hline $\begin{array}{l}\text { Restaurant \& } \\
\text { Hotel }\end{array}$ & - & - & - & - & - & - & - & 107.99 & 117.82 & 134.10 \\
\hline $\begin{array}{l}\text { Miscellaneous, } \\
\text { Good \& Service }\end{array}$ & $2,526.70$ & $2,775.97$ & $3,080.67$ & $3,703.96$ & $4,322.25$ & 448.44 & $5,930.05$ & 111.05 & 129.40 & 136.73 \\
\hline $\begin{array}{l}\text { All items less } \\
\text { farm Produce and } \\
\text { Energy }\end{array}$ & - & - & - & - & - & - & - & 107.52 & 21.159 & 134.34 \\
\hline $\begin{array}{l}\text { All item less farm } \\
\text { Produce }\end{array}$ & - & - & $3,849.20$ & $3,901.50$ & $4,788.20$ & $4,795.20$ & $5,082.90$ & 112.07 & 129.44 & 148.80 \\
\hline All items & $2,638.00$ & $2,919.62$ & $3,149.16$ & $3,357.56$ & $3,590.49$ & $4,267.96$ & $4,817.80$ & 105.96 & 121.85 & 143.61 \\
\hline
\end{tabular}

Table 1:

Table 2: Annual Average COMPOSITION CONSUMER PRICE INDEX (COMBINED RURAL AND URBAN CENTRES)

Source: National Bureau of Statistics

Note: The Base for $1999-2002$ is $1988=100$ the Base Year for 2003 is May, 2003=100 
More recently, the faster growth of food prices has become even clearer. Between June and July 2006, the consumer price index jumped from $16.6 \%$ to $17.7 \%$ (BBC 2007). In a similar vein, Effiong (1998) suggested that high level of inflation experienced in the country with arbitrary price fluctuations could contribute to wide seasonal price spreads for food grains. Price variations in the overall index since 1996 have remained fairly stable and this has also been the case for the food price index up to the beginning of 2003. This suggests that prices may also have become increasingly unstable.

\section{Linkages Between Food Security And Poverty}

Most Nigerians suffer from lack of food security mainly caused by a lack of purchasing power. Food security though interpreted in many ways is defined here as access by all people at all times to enough food for an active healthy life. Its essential elements are the availability of food and the ability to acquire it. Conversely, food insecurity is the lack of access to sufficient food and can be either chronic or transitory. Chronic food insecurity is a continuously inadequate diet resulting from the lack of resources to produce or acquire food (Reutlinger, 1987).

Food security goes much beyond the question of energy intake. Individuals require a balanced diet in terms of macro and micronutrients to maintain a healthy nutritional status. Presently, the food security challenge shifts from insufficient energy consumption towards ensuring balanced diets to prevent the range of non-communicable disease that poor nutritional status can cause. Food insecurity is being associated with low household income, physical limitations of the household and low educational attainment. In a study Lovendal et al (2007) observed that food insecure people were less likely to be frequent consumers of fruits, green vegetables and salad. The major pervasive cause of food insecurity is poverty resulting in lack of access to adequate food for an active and healthy life (Tollens, 1998).

Oladunni (1999) stressed that though poverty is a worldwide phenomenon, Nigeria is observed to be one of the poorest countries in the world. At least 45 percent of the population lives below the poverty line, while 67 percent of the poor are extremely poor [FOS 2005]. The poverty profile in Nigeria spreads between the rural dwellers and urban inhabitants. For instance, the share of the rural areas in the population of the poor rose marginally from 66 percent to 68.9 percent in 1996, implying that about 48 million Nigerians in rural areas were poor in 1996. The urban dwellers are not better off, there is growing urban poverty amongst urban dwellers and the marginalized middle income class. The middle income workers in the formal employment sector have had their wages and salaries reduced in actual terms, becoming impoverished by the depreciation of the Naira and inflation (Ukwu, 1995). This phenomenon has baffled development observers on how the poverty seed is allowed to germinate in the midst of abundant human and natural resources (Olulu, 2005 and IFAD, 2007). Data from (FOS, 2005) on poverty profile in Nigeria as can be observed in Table 3 indicates that the incidence of poverty increased from 27.2 per cent in 1980 to 46.3 per cent in 1985. It thereafter increased to 65.6 percent in 1996 but declined to 57.8 percent in 2004 . The United Nations Development Programme (UNDP), Human Development Index (HDI) for 2000 ranked Nigeria the $142^{\text {nd }}$ position in the world with HDI of 0.40 among the poorest countries. Also between 1980 and 1996 the population of poor Nigerians increased in absolute terms. The percentage of the core poor increased from 62 percent in 1980 to 70.2 percent in 2004 (FOS, 2005). 


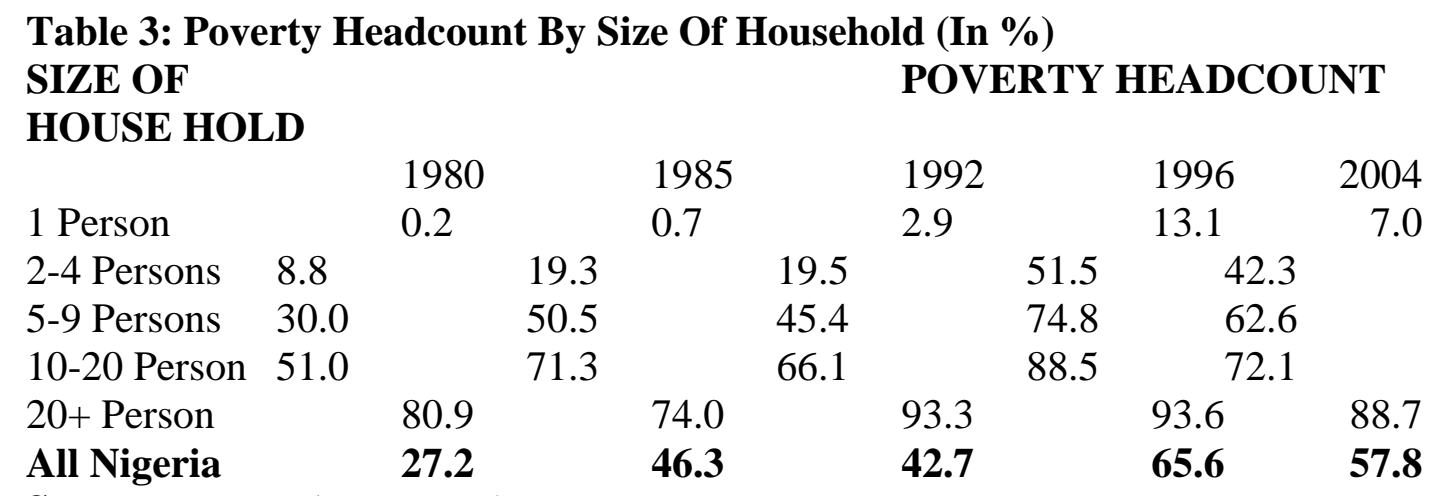

Source: National Bureau of Statistics

IFAD, (2005) argued that limited education opportunities, civil unrest and poor health occasioned by inadequate nutrition perpetuates the poverty cycle. World Bank (1986) report on sub-Saharan Africa identified inadequate access to employment opportunities and low growth rate of investment as the root causes of poverty. It is the poverty syndrome occasioned by a lack of purchasing power coupled with food price inflation that renders the populace vulnerable to food insecurity. This is based on the premise that food consumption consumes about 98 percent income of the poor. Effiong (2005) in a study observed that the Marginal Propensity to Consume (MPC) for low income groups of civil servants was 0.98 while that of high income groups of civil servants was 0.79 . The findings of the study strongly suggested that labour was grossly under-remunerated as a larger percentage of workers income is devoted to food consumption thus leaving nothing for savings. The study concluded that any measure that can reduce food prices would greatly improve the real income of workers.

\section{Impact Of Food Price Inflation On Food Security}

Lovendal et al (2007) argued that food price fluctuations can lead to macroeconomic fluctuations which may dampen investments and reduce economic growth. In standard welfare analysis, it is assumed that households choose between various combinations of food and other consumption goods. For non -poor households this implies trading off preferences for food against other types of consumption goods. On the other hand, poor and or food insecure households face a significant risk of food consumption falling below a critical level in regards to health and survival. The existence of such a level can be considered to imply discontinuous preferences because malnutrition and in the worst case, starvation is a state any household will avoid at any cost. However standard welfare analysis assumes continuous preferences and will therefore not be able to measure the true costs of price instability if the probability of survival is reduced by a price increase. Myers (2006) estimated that if higher food prices reduce the probability of survival by one percent, the household would need to have their incomes compensated by five percent in order for them to be as well of as they would have been, had they faced a one per cent higher probability of survival. The relative nature of this result illustrates the problems. Can one expect that a household living on the margin of survival would demand 5 percent of their income in order to have their chance of survival further reduced? The result is also strictly theoretical and assumes a certain risk aversion in order to hold. As premature death is the most severe outcome of inadequate calorie intake, it is argued that the cost of food price instability could be high for very poor households because very high food prices worsen the nutritional status to a level where labour productivity is seriously affected (World Bank, 2005).

What happens to food consumption at household level when food prices change depends on the commodity type and can be analyzed by looking at demand elasticities for food in 
relation to changes in income and prices. Studies like [Allison-Oguru and Ubani [1999], Omojola [2004] and Leftwich [1979] argued that own price elasticities for basic food items such as cereals are quite low because they cannot be substituted by other food items. In contrast, the price elasticities for other food items, such as meat are usually high, meaning that households make substantial shift between expensive and cheaper food items when prices increase.

In general, price increases for some food groups can lead to a fall in real income for poor households because price increases for inelastic food items lead to higher relative spending on these items. This can in some circumstances, result in a drop in calorie intake for households spending a large share of their income on food and with limited ability to smoothen consumption. This is typical for households spending high shares of their income on food. In a similar study, Abdulai and Aubert (2004) observed that calorie consumption in Tanzania dropped when the price of either maize or rice went up. Still, a price increase for an inelastic food item does not necessarily need to cause a drop in calorie intake if the household responds by maintaining consumption of an (energy-intensive) inelastic good at the cost of some more elastic food item such as meat, vegetables and fruits. Overall calorie intake may be maintained, but at the expense of the dietary diversion which can mean less access to important nutrients, vitamins etc and this affects nutritional status. In summary, how changing food prices affect food security depend on the characteristics of the country, the commodity and the particulars of its economy and food system. While it is difficult to measure the exact costs of food instability, it has been argued that the total macroeconomic costs are likely to be quite small for countries that are diversified in its production and food consumption (World Bank, 2005). Some household level studies by Block (2004) suggested that for poorer households, the level of food prices can affect nutritional outcomes. Poorer households generally, are more adversely affected by food price inflation in part because they spend relatively higher proportions of their income on food. Thus the present hike in food price is likely to derail Nigeria's path towards achieving the Millennium Development Goal (MDG) 1 on hunger target. Health effects of nutritional deficiencies as a result of poor dietary habits and lifestyle will remain.

\section{CONCLUSION}

It has been observed that the impact of food price increases on those poor farmers who derive their income from food production is negative as food price increases is not reflected in higher farm gate prices. A rise in the price of food does not necessarily raise the real incomes of food producers. Such phenomenon may not induce a downward shift of the supply curve in the long run due to lack of short term incentives to invest, innovate and adopt technical changes that could boost food supplies.

\section{RECOMMENDATIONS}

This study recommends adequately maintained rural feeder roads, banning of motor park touts, halting of police extortion at check points and provision of cheap and adequate supply of fuel as it could go a long way to mitigate food price inflation. Attempts should also be made to subsidize food prices for the poor just like in some advanced economies. Reutlinger (1987) contended that the ultimate solution is to provide people facing chronic food insecurity with opportunities to earn adequate incomes and to assure an abundant food supply from domestic production.

\section{REFERENCES}

Abdulai, A and Aubert, D. (2004) Nonparametric and Parametric Analysis of Calorie Consumption in Tanzania. Food policy 29 ppl13 -129. 
Alliison - Oguru, E.A and Ubani N.J [1999] Empirical Analysis of Aggregate Demand for Meat in Port Harcourt metropolis, Nigeria 1980 - 1989

Balogun, E.D. (1986) Agricultural Development Strategies in Nigeria: Past, Present and Future in Nigeria's Agricultural Outlook (with Special Reference to Budgets)(eds) Okorie A. and M. O. ijere

BBC, (2007) Central Bank of Nigeria Raises Rates. ww.news.bbc.co.uk/1/ni/business

Block, S.A. (2004) Macro Shocks and Micro Outcomes: Child Nutrition During Indonesia's Crisis. Economics and Human Biology 2 issue 2, pp 21- 44

CP1,(2004) Frequent Protests Against Fuel Price Hikes in Nigeria in Centre for Petroleum Information Journal www.petroinfongeria Com/faq. Html

Effiong J.A. L. (1998) Economic Analysis of Food Grains Marketing in Kaduna State, An unpublished MSc Thesis, RSUST, Port Harcourt.

Effiong, J. A. L.. (2005) Impact of New Minimum Wage on Food Consumption and Expenditure Pattern of Civil Servants: A Case Study of 1vo Local Government Area of Ebonyi State, Nigeria International Research Journal for Development 7:51,

FGN, (1989) Agricultural Policy for Nigeria, Ministry of Agriculture, Water Resources and Rural Development, Lagos, Nigeria

FOS, (2005) Annual Abstract of Statistics, Abuja, Nigeria IFAD, (2007) Rural Poverty in Nigeria www. Ifad.org

Igben, M.S (2001) Window into the Anatomy and Dynamics of Poverty among the Neglected Rural Majority of Rivers State. An inaugural lecture delivered on $12^{\text {th }}$ December 2001 at RSUST, Port Harcourt.

Leftwich, R.H [1979] "The Price System and Resource Allocation $7^{\text {th }}$ Edition, The Darsen Press, Hinsdale, Illionois, USA pp 383-385.

Lovendal, C.R, K. T. Jakobsen and A. Jacque (2007) Food Prices and Food Security in Trinidad and Tobago www.fao.org/es/esa.

Myers, R. J. (2006) Costs of Food Price Fluctuations in Low - Income Countries, Food policy, . 21 pp 288-301

Oladunni, P. (1999) The Dimensions of Poverty in Nigeria. Central Bank of Nigeria Bulletin.23, 4

Olulu, R. M. (2005) An Empirical Investigation of Poverty in Nigeria International Research Journal for Development 51.

Omojola , J. T (2004) Analysis of the demand for and supply of rice in some selected L.G.A. of Niger State: An unpublished MSc thesis RSUST, Port Harcourt.

Reutlinger, S. (1987) Food Security and Poverty in Developing Countries in Food Policy: Integrating Supply Distribution and Consumption (eds) Gittinger, J. P., L. Leslie and C. Hoisington, John Hophkins Press London

Sebiola , D.O (2004) Analysis of income Distribution Among Rural Farmers in Kwara State. An unpublished MSc thesis RSUST, Port Harcourt.

Tollens, E. (1998) Food Security: Incidence and Causes of Food Insecurity Among Vulnerable Groups and Coping Strategies in Food Insecurity in ACP Countries Policy and Programme Interventions Affecting Vulnerable Groups Proceedings of a CTA Seminar held at Lenver, Belgium $26^{\text {th }} 30^{\text {th }}$ October 1998

Ukwu, U. (1999) Adjustment, Income Distribution and Poverty in Macro Economic Policy Issues in an Open Developing Economy. A Case Study of Nigeria NCEMA, Abuja.

Vanguard Newspaper (2007) FAO Forecasts Continued High Cereal Prices.

Agriculture Page of Business Vanguard $9^{\text {th }}$ November 2007 Issue www.vanguardng. org.

World Bank (1984) Poverty Lines, Profiles and Indications: Poverty Reduction

Handbook, World Bank Washington DC.

World Bank (2005) Managing Food Price Risks and Instability in an Environment of Market Liberalization. World Bank, Agriculture and Rural Development Department, Washington DC. 